\title{
IMPLEMENTASI PENDIDIKAN KARAKTER PADA SISWA DI SMA NEGERI 3 DENPASAR
}

\author{
Oleh \\ I Made Arsa Wiguna \\ Institut Hindu Dharma Negeri Denpasar \\ imadearsawiguna@gmail.com
}

\begin{abstract}
ABSTRAK
Tulisan ini bertujuan untuk mendeskripsikan implementasi pendidikan karakter pada siswa di SMA Negeri 3 Denpasar. Keberadaan sekolah tersebut tidak perlu diragukan lagi karena segudang prestasi telah diraih. Hal itu tidak lepas dari pendidikan karakter yang secara nyata diwujudkan dalam pemeblajaran di kelas maupun di luar kelas. Kepala Sekolah dan para guru meyakini bahwa tujuan pendidikan harus dikembalikan kepada tujuan semula yakni membentuk karakter yang baik.
\end{abstract}

Kata-kata kunci: Implementasi pendidikan karakter, siswa, SMA Negeri 3 Denpasar

ABSTRACT

This paper aims to describe the implementation of character education to students in SMA Negeri 3 Denpasar. Its don't need to doubt about the existence of this high school because of the achievements. Its can not be separated from character education that is manifestly implemented in the in the classroom or outside the classroom learning. Principals and teachers believe that the purpose of education should be returned to the original goal of forming a good character.

Keywords: Implementation of character education, students, SMA Negeri 3 Denpasar

\section{PENDAHULUAN \\ Pendidkan menjadi modal dasar} pembangunan bangsa dan peradaban. Pendidikan memegang peranan penting dalam membentuk kepribadian seseorang, oleh karena itu,memprioritaskan pendidikan meruapakn hal yang wajib dilakukan pemerintah, termasuk seluruh pemegang kebijakan pendidikan. Melihat fenomena saat ini bahwa orientasi pendidikan cenderung dipengaruhi ideologi pasar. Seperti yang dinyatakan oleh Nuryatno (2014: 11) bahwa tarik-menarik kepentingan antara idealisme (berbasis nilai-nilai akademik) dan pragmatisme (berbasis pada nilai-nilai korporasi dalam dunia pendidikan selalu terjadi. Pragmatisme identik dengan ideologi pasar yang pada dasarnya sangat jauh berbeda dengan ideologi pendidikan yang mengedepankan nilai-nilai etis humanistik. Sejalan dengan pemikiran

tersebut, Nashir (2013: 16) menyatakan bahwa pendidikan saat ini ternyata hanya melahirkan manusiamanusia yang cerdas otak dan keahliannya, tetapi lembek dan rapuh moral dan tingkah lakunya. Kecerdasan otak dan keahlian bahkan disalahgunakan untuk melakukan sesuatu yang menyimpang, yang berlawanan dengan nilai-nilai moral, budaya, dan agama. Senada dengan Nashir, Daryanto dan Darmiatun (2013 : 4) mengungkapkan bahwa pendidikan sekarang ini masih melahirkan generasi yang ahli dalam pengetahuan sains dan teknologi. Hal ini bukan merupakan suatu prestasi, karena pendidikan seharusnya menghasilkan generasi dengan kepribadian yang unggul dan sekaligus menguasai ilmu pengetahuan. Disamping itu, ada indikasi kuat 
pengembangan ilmu pengetahuan dan sains teknologi yang dilakukan oleh Departemen Pendidikan Nasional tidak memiliki hubungan yang kuat dengan pendidikan karakter peserta didik. Untuk itu setiap sekolah diharapkan mengembalikan tujuan pendidikan yakni untuk mebentuk karakter yang baik. Demikian pula di SMA Negeri 3 Denpasar yang menunjukkan bahwa kepala sekolah dan guru secara nyata mengimplementasikan pendidikan karakter kepada para siswanya. Kedelapanbelas nilai-nilai karakter bangsa tersebut diterapkan dalam setiap kegiatan kurikuler dan ekstra kurikuluer di sekolah tersebut, sehingga tidak salah jika SMA Negeri 3 Denpasar memiliki prestasi yang sangat baik di bidang kurikuler maupun non kurikuler. Segudang prestasi diraih oleh para Siswa SMA Negeri Denpasar. Implementasi pendidikan karakter memang tidak cukup hanya peran pemerintah saja, dan harus benar-benar diwujudkan menjadi budaya sekolah. Lebih lanjut akan dipaparkan mengenai implementasi pendidikan karakter pada siswa di SMA Negeri 3 Denpasar.

\section{PEMBAHASAN}

\subsection{Religius}

Implementasi sikap religius di SMA Negeri 3 Denpasar tercermin dalam beberapa hal. Pertama yakni dalam pelaksanaan Trisandhya yang rutin dan secara konsisten dilakukan oleh siswa di kelas dengan didampingi guru setiap pagi dan siang hari. Tidak hanya itu, siswa dengan kesadaran masing-masing bersembahyang di Padmasana sekolah ketika memasuki sekolah dan meninggalkan sekolah.

Kedua, ketika hari suci Purnama, seluruh civitas menggunakan pakaian adat dan pada hari tersebut diisi dengan kegiatan budaya, seperti membuat klakat, sengkui, pejati, canang, dan sarana persembahyangan lainnya. Sedangkan pada saat hari suci Tilem, seluruh civitas tetap menggunakan pakaian kerja, namun pagi harinya diisi dengan persembahyangan bersama. Selain itu, pada hari suci Purnama maupun Tilem juga diisi dengan kegiatan dharmawacana, dan makidung. Dalam pelaksanaan makidung, para siswa dibagikan teks-teks kidung, lalu dengan dipimpin oleh guru agama bersama-sama melantunkan kidung tersebut. Hal tersebut sebagai bentuk penanaman nila-nilai religius secara konsisten oleh guru kepada para siswa.

Ketiga, penerapan nilai religius nampak ketika para siswa dengan sikap anjali (tangan tercakup di depan dada) mengucapkan salam "Om Swastyastu kepada guru atauou pegawai di lingkungan sekolah. Hal ini sebagai bentuk aplikasi ajaran Catur Guru (empat guru yang harus dihormati yakni Guru Swadhyaya (Ida Sang Hyang Widhi Wasa), Guru Rupaka (Orangtua di rumah), Guru Pengajian (guru di sekolah), dan Guru Wisesa (pemerintah).

Kemudian lebih lanjut aplikasi nilai-nilai religius di SMA Negeri 3 Denpasar terlihat ketika pihak sekolah memberikan kesempatan seluasluasnya bagi para siswa terutama siswa di kelas $\mathrm{X}$ dan XI untuk mengikuti kegiatan yoga setiap hari Senin-Kamis jam 16.30-18.00. Kegiatan yoga ini baik untuk kesehatan dengan mengatur jalannya nafas dan meningkatan daya konsentrasi seseorang. Yoga tidak hanya milik para yogi saja, namun kini sudah diminati oleh semua kalangan mulai dari anak-anak hingga dewasa. 


\subsection{Jujur}

Sikap jujur hendaknya dimiliki oleh setiap orang, karena ketika kejujuran sudah tertanam dalam diri, maka tidak akan ada ketakutan karena Tuhan akan selalu melindungi umatnya yang jujur.

Demikian pula di SMA 3 Denpasar, kejujuran ini sudah ditanamkan dalam bentuk latihan dan uji kejujuran yakni sebuah kantin yang diberi nama kantin kejujuran. Di atas ruang kantin kejujuran ini dipasang slogan yang bersifat mendidik agar semua warga sekolah yang berbelanja disana memahami makna dari sebuah kejujuran seperti tampak apada gambar berikut ini

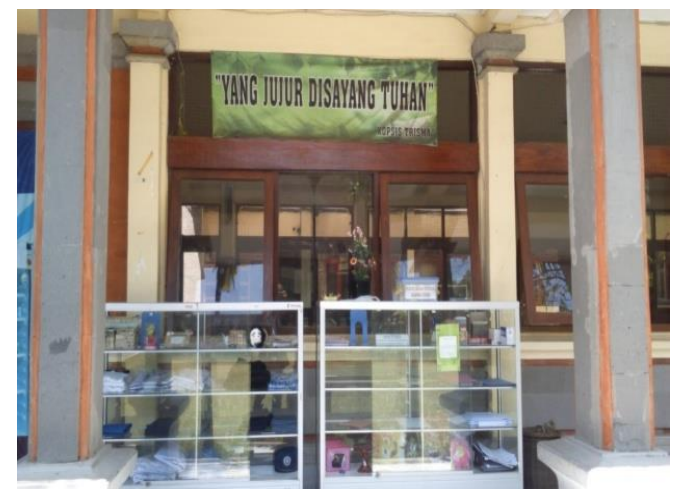

Sumber: dokumentasi penulis 2015

Gambar 2.1

Kantin Kejujuran SMA 3 Denpasar

Kantin ini tidak memiliki pelayan layaknya kantin secara umum. Ada beberapa barang yang dijual di kantin ini, dan setiap warga sekolah yang hendak membeli sesuatu, di kantin ini telah disediakan kotak untuk meletakkan uang dan mengambil uang kembalian secara swalayan dan semua siswa membuktikan kejujuran mereka ketika melakukan pembelian. Meskipun sebenarnya peluang untuk melakukan tindak pencurian itu ada, namun berdasarkan keterangan informan, tidak tidak terlintas di pikiran siswa atau warga sekolah lainnya untuk melakukan hal itu.
Mereka sudah mengerti betul makna dari sebuah kejujuran dan akibatnya bila menyimpang dari kejujuran. Siswa sudah terbiasa berperilaku jujur dengan membeli dan membayar sendiri barang yang diambil sesuai dengna harga yang tertera

Kantin kejujuran ini mendapat gelar juara di Propinsi Bali sebagai satusatunya sekolah yang mempertahankan kejujuran. Tentu bukan hal yang mudah untuk mewujudkan kejujuran, tapi jika ditanamkan sejak dini maka kejujuran itu akan menjadi sebuah kewajiban.

\subsection{Toleransi}

Sikap toleransi dalam hal menghargai kepercayaan dan keyakinan orang lain sudah diajarkan oleh orangtua dan guru di sekolah, bahkan dalam ajaran agama Hindu sekalipun umat diajarkan untuk memiliki sikap toleransi, karena kebenaran menurut seseorang belum tentu benar bagi orang lain demikian sebaliknya. Sikap toleransi yang ditunjukkan di lingkungan SMA 3 Denpasar ketika pelaksanaan hari suci Purnama, semua warga sekolah baik yang beragama Hindu maupun NonHindu secara bersama-sama mengikuti kegiatan budaya yang telah disiapkan, dan semua warga sekolah menggunakan pakaian adat selayaknya. Kemudian ketika siswa bertemu dengan guru, tanpa pengecualian mereka wajib mengucapkan salam panganjali "Om Swastyastu". Menurut Suwara (wawancara 24 Agustus 2015), kegiatan budaya seperti membuat klakat, sengkui, pejati, canang, kwangen, dan sejenisnya merupakan bagian dari budaya Bali. Demikian pula dengan mengucapkan salam Om Swastyastu tidak serta merta berarti menghindukan siswa Non-Hindu, namun itu lebih kepada penanaman 
sikap toleransi sejak dini dan itu juga tidak dapat dilepaskan dari budaya Bali.

\subsection{Disiplin}

Penerapan disiplin merupakan kunci sebuah keberhasilan. Disiplin ini memiliki pengaruh yang besar dalam kehidupan seseorang. Disiplin tidak hanya menjadi kewajiban militer, namun setiap orang harus menanamkan sikap ini sejak dini. SMA 3 memang sudah dikenal karena kedisplinanya. Ketika siswanya masih menggunakan sepeda untuk berangkat ke skolah, pihak OSIS akan secara rutin melakukan razia bagi siswa yang membawa kendaraan bermotor. Demikian pula ketika siswa yang berpakaian tidak sesuai aturan maka sanksi itu adalah sebuah kepastian. Hal ini pada dasarnya bertujuan untuk melatih kedisiplinan siswai. Saat ini, hukuman disiplin yang diterapkan kepada siswa sifatnya diarahkan untuk lebih mendidik. Siswa yang terlambat datag ke sekolah, diberikan sanksi disiplin untuk merangkum da buku apa saja di perpustakaan sekolah. Hukuman ini tentu sifatnya sangat mendidik.Siswa yang mendapat sanksi akan secara tidak langsung menambah wawasan dan pengetahuan mereka dengan membaca buku lalu membuat ringkasannya. Apa pula sebuah locker kedisiplinan yang dipasang di dekat ruang guru. Bagi siswa yang melakukan pelanggaran akan mengambil kartu pelanggaran yang dimasukkan ke dalam locker sesuai dengan kelasnya masing-masing. Locker kedisiplinan seperti nampak pada gambar berikut sifatnya permanen untuk melatih kedisiplinan siswa dalam berbagai hal.

Selain locker kedisplinan tersebut, pihak sekolah juga menerapkan disiplin berupa absen online. Dengan menggunakan absen online ini, siswa diwajibkan untuk menunjukkan kartu mahasiswa dan wajahnya sendiri agar terdata oleh sistem dan dinyatakan hadir di sekolah, sehingga tidak ada peluang untuk melakukan pelanggaran seperti membolos dan sejenisnya. Demikian juga ketika siswa memasuki perpustakaan, siswa tidak diperbolehkan menggunakan sepatu ke dalam ruang perpustakaan, dan tidak diperkenankan untuk naik ke ruangan di lantai II tanpa didampingi oleh guru. Sebelum mereka dapat melakukan kegiatan di perpustakaan, baik itu membaca, belajar, meminjam dan mengembalikan buku, mereka wajib melengkapi data kunjungan digital seperti pada gambar berikut.

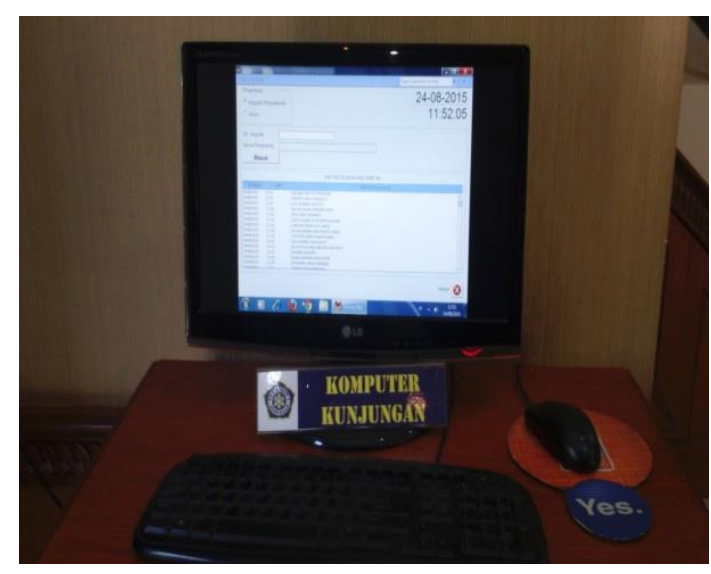

Sumber: dokumentasi penulis 2015

Gambar 2.2

Komputer Kunjungan di Perpustakaan

\subsection{Kerja Keras}

Untuk mencapai tujuan yang diharapkan, diperlukan usaha dan kerja keras disamping disiplin yang kuat. Kerja keras ditunjukkan oleh siswa SMA 3 Denpasar ketika diberikan tugas untuk mempersiapkan sebuah kegiatan, termasuk menyusun kepanitiaan yang terdiri dari guru dan siswa. Demikian pula kegiatan yang dilakukan dalam upaya regenerasi 
pengurus ekstra, dan penggalian dana yang memerlukan semangat berorganisasi dan kerja keras yang mantap.

Selain itu, para siswa yang mengikuti olimpiade memerlukan kerja keras dan usaha yang tidak mudah. Mereka terpilih melalui seleksi yang ketat dan dibina oleh dosen yang memiliki kualifikasi di bidang tersebut. Sehingga dengan kerja keras dan disiplin yang kuat, mereka mampu meraih gelar juara dalam olimpiade tersebut. Ada segudang prestasi yang telah diraih oleh siswa SMA 3 Denpasar baik di bidang akademis dan non akademis. Tentunya semua itu bisa diraih dengan kerja keras, disiplin yang memang dilatih sejak menjadi siswa di SMA 3 Denpasar.

\subsection{Kreatif}

Dalam hal kreativitas, kemampuan para siswa SMA3 Denpasar tidak perlu diragukan lagi. Beberapa contoh sikap kreatif siswa di sekolah ini antara lain dengan dibentuknya tim kreativitas cipta musik barang bekas. Alat-alat musik yang digunakan berasal dari barang bekas. Demikian pula ketika penyambutan tamu penting, pihak sekolah tidak hanya menyambut dengan menggunakan gambelan saja, namun juga diselipkan penyambutan dengan menggunakan alat musik dari barnag bekas tersebut, dan yang lebih kreatif lagi adalah pakaian yang digunakan juga berasal dari barnagbarang bekas. Selain dapat membantu pengelolaan sampah plastik dan barang bekas yang sudah tidak bermanfaat lagi, ternyata di tangan para siswa SMA 3 Denpasar menjadi sebuah karya yang unik dan menarik. Begitu pula denga perlombaan mengumpulkan sampah plastik dan membuat karya seni yang berasal dari sampah plastik. Terbukti para siswa ini mampu menciptakan karya seni dimaksud.

Selain itu, pihak sekolah juga menyelenggarakan kegiatan pendidikan karakter untuk mengisi waktu libur sekolah. Kegiatannya menyerupai inbound dan di sekolah dibuatkan 5 pos, dan siswa dibagi ke dalam kelompok-kelompok. Setiap kelompok wajib menyelesaikan tantangan di setiap pos yang berkaitan dengan pendidikan karakter. Kemudian kreativitas di bidang pembelajaran ditunjukkan melalui kegiatan yang disebut dengan aplikasi pembelajaran. Siswa diajak terjun langsung ke lapangan yang berkaitan dengan mata pelajaran yang disampaikan. Misalkan mata pelajaran Pendidikan agama dan budi pekerti, para siswa diajak untuk berkunjung ke PHDI, ke pura. Begitu juga dengan mata pelajaran Bahasa Indonesia, siswa diajak ke balai penelitian bahasa, mata elajaran sejarah biasanya diajak berkunjung ke museum, dan seterusnya.

\subsection{Mandiri}

Sikap mandiri siswa di SMA 3 Denpasar salah satunya ditunjukkan ketika mereka mengumpulkan sampah plastik yang ada di sekolah lalu dijual, dan hasilnya digunakan untuk menambah uas kas. Siswa dilatih untuk sedini mungkin belajar hidup mandiri, tidak hanya meminta kepada orangtua. Dengan melakukan kegiatan ini diharapkan membangkitkan semangat kemandirian dan kewirausahaan siswa agar kelak tidak melulu memikirkan untuk bekerja dimana namun mewujudkan sebuah lapangan kerja minimal untuk dirinya sendiri.

Sikap mandiri lainnya dapat diamati ketika siswa ditugaskan untuk melakukan presentasi menggunakan 
projector. Mereka sudah dibiasakan untuk mengambil perlengkapannya sendiri, kemudian memasang dan mengoperasikannya hingga mengembalikannya ke tempat semula. Guru juga tidak banyak memberikan ceramah, namun melatih siswa untuk menyampaikan idenya melalui presentasi. Siswa dilatih untuk terbiasa tampil dan berbicara di depan kelas.

Selain melatih kemandirian, hal ini juga mampu melatih rasa percaya diri siswa. Demikian pula ketika guru berhalangan hadir atau ada urusan penting sehingga terlambat hadir di kelas, maka siswa lebih memilih untuk berkunjung ke perpustakaan, dan tidak ada siswa yang berkeliaran di halaman sekolah. Siswa juga diwajibkan dan terbiasa untuk membersihkan kelas secara mandiri. Ketika guru masuk ke ruangan kelas, siswa diminta untuk melihat ke sekitarnya untuk memungut jika ada sampah di sekitar mereka.

Begitu pula kegiatan ekstra yang memberikan ruang bagi siswa untuk belajar mandiri. Seperti nampak pada gambar berikut, para siswa yang memilih kegiatan ekstra Karya Ilmiah Remaja sedang mendengarkan arahan dari pengurusnya tanpa didampingi guru atau pembimbing.

\subsection{Demokratis}

Sikap demokratis ditunjukkan ketika pemilihan pengurus OSIS yang melibatkan melibatkan semua warga sekolah. Kegiatannya hampir menyerupai kegiatan Pemilu. Sebelum dipilih, para calon pengurus diberikan kesempatan untuk berorasi tentang visi misi mereka masing-masing dan semua warga sekolah diberikan kesempatan untuk bertanya atau mendebat calon pengurus tersebut.

Semngat demokrasi benar-benar diterapkan sehingga tercapai mufakat. Pemilihan pengurus OSIS ini berlangsung tertutup dan hanya diperuntukkan bagi warga sekolah dan semuanya wajib hadir untuk memberikan hak suara mereka. Setelah memberikan pilihan, mereka wajib mencelupka salah satu jari tangan ke dalam tinta sebagai bukti telah memilih dan menghindari kecurangan layaknya pemilihan kepala daerah dan sejenisnya.

\subsection{Rasa ingin tahu}

Rasa ingin tahu siswa di SMA 3 Denpasar telah mendorong mereka untuk meraih segudang prestasi. Rasa ingin tahu mereka terlihat dari kegiatan penelitian yang dilakukan oleh siswa dan guru untuk menghasilkan suatu karya yang bermanfaat baik bagi sekolah, pemerintah dan masyarakat. Antusiasme mereka dalam mengamati, meneliti dan menghasilkan karya cukup tinggi dilihat dari prestasi yang diraih para siswa di bidang penelitian dan karya tulis ilmiah. Pihak sekolah memfasilitasi kegiatan penelitian ini dengan menyiapkan ruangan khusus untuk melakukan penelitian sehingga semakin mendorong rasa ingin tahu siswa. Demikian pula ketika belajar di kelas, siswa cukup aktif untuk bertanya tentang apa yang didengar, dibaca dan dipelajari.

\subsection{Semangat Kebangsaan}

Semangat kebangsaan yang tinggi ditunjukkan oleh siswa SMA 3 Denpasar dengan mendaki gunung dalam merayakan Hari Kemerdekaan RI 17 Agustus. Siswa kelas XII diberikan kesempatan mendaki ke Gunung Agung, kelas XI ke Gunung Abang, sedangkan kelas $\mathrm{X}$ tetap di sekolah dan mengikuti upacara pendidikan karakter. Upacara pendidikan karakter ini sendiri dilaksanakan sebulan sekali. Semua perangkat upacara ditentukan secara bergilir, dan mereka wajib melaporkan tentang kerbadaan sekolah dan 
lingkungannya. Sebelumnya mereka melakukan observasi ke seluruh lingkungan sekolah untuk melihat halhal yang perlu mendapat perhatian, misal ada kursi atau meja di kelas yang rusak, atau jika ada siswa yang melakukan pelanggaran, semua itu dicatat dan ketika upacara pendidikan karakter, semua itu dilaporkan untuk segera mendapat tindakan lebih lanjut. Dalam upacara ini, semua peserta wajib menggunakan pakaian pramuka.

Selain itu ketika perayaan Hari Kemerdekaan RI, siswa Kelas X diberikan kebebasan untuk membuat acara spontanitas bertema merah putih dengan aransemen lagu di sekolah. Kelompok teater Trisma juga diberikan kesempatan untuk membuat acara drama musikal.

\subsection{Cinta tanah air}

Cinta tanah air secara sederhana ditunjukkan melalui pelaksanaan upacra bendera setiap hari Senin secara rutin. Selalin itu juga ditunjukkan dengan rasa bangga terhadap budaya daerah dan berusaha melestarikannya seperti yang dilakukan oleh para siswa SMA 3 Denpasar dengan mengikuti kegiatan menabuh dan menari Bali serta tari krasi baru. Tidak jarang mereka mengikuti pentas seni dan meraih gelar juara. Hal ini sebagai bukti dedikasi dan kecintaan mereka terhadap budaya daerah yang merupakan akar dari budaya nasional

\subsection{Menghargai prestasi}

Prestasi yang diraih siswa SMA 3 Denpasar tidak perlu diragukan lagi, berbagai prestasi akademis dan non akademis telah diraih, dan pihak sekolah memberikan penghargaan atas presasi yang telah diraih oleh para siswanya. Suwara (wawancara 24 Agustus 2015) menjelaskan bahwa siswa yang akan mengikuti olimpiade nasional dipersiapkan dengan matang.
Mereka masuk ke dalam kelompok tim optimasi. Mereka diijinkan untuk tidak mengikuti kegiatan pembelajaran selama 2 bulan, dan dibina oleh dosen utuk mata pelajaran yang akan diikuti dalam olimpiade.

Suwara menambahkan, bagi siswa yang memperoleh juara umum mendapat pembebasan SPP berkategori. Mereka juga diberikan hadiah berupa hardisk external, flasdisk, dan buku-buku penunjang. Selain itu, setiap sebulan sekali diumumkan kelas terbersih dan terjorok. Bagi kelas terjorok diberikan hadiah berupa Topeng Tua, sedangkan kelas terbersih diberikan hadiah berupa Topeng Dalem.

Demikian pula bagi siswa yang berprestasi baik di bidang akademis ataupun non akademis termasuk prestasi sebagai juara pada olimpiade diberikan penghargaan berupa laptop, ipad, dan yang terpenting foto mereka dipajang di beberapa tempat strategis seperti di lantai 2 ruangan perpustakaan. Hal ini sebagai bentuk penghargaan kepada siswa berprestasi, disamping untuk memotivasi siswa lainnya untuk berprestasi. Seperti yang tampak pada gambar berikut.

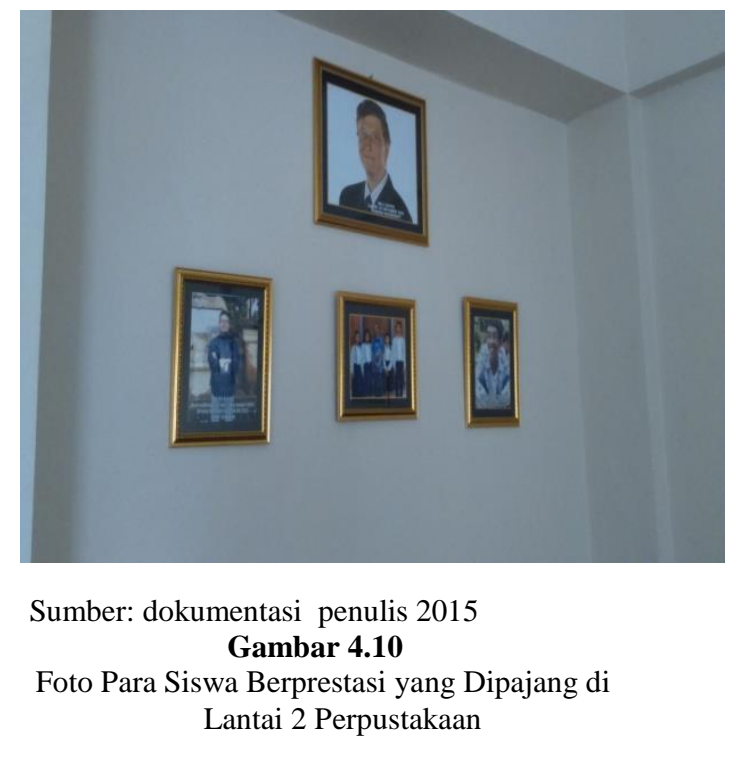




\subsection{Bersahabat/ komunikatif}

Sikap bersahabat/ komunikatif disini dimaksudkan sebagai bentuk sikap yang menujukkan rasa senang berbicara, bergaul, dan bekerja sama dengan orang lain. Hal ini ditunjukkan dengan terbukanya komunikasi antara siswa dan guru di SMA 3 Denpasar. Tidak ada jarak atau dinding pemisah antara guru dan siswa. Meskipun demikian, siswa tetap menjaga sikap dan rasa hormat mereka kepada guru. Seperti yang dapat dilihat pada gambar berikut menunjukkan bentuk sikap komunikatif yang terjalin antara guru dan siswa.

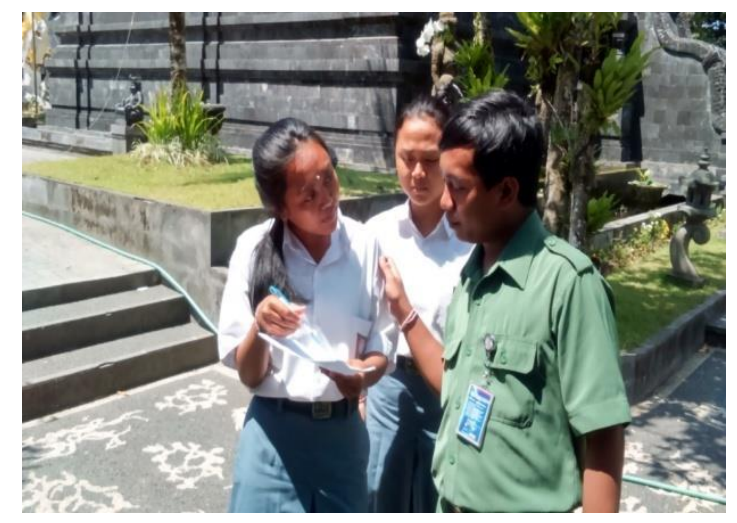

Sumber: dokumentasi penulis 2015 Gambar 4.11

Sikap Komunikatif yang Terjalin antara Guru dan Siswa

Demikian pula dengan sikap antar siswa yang tidak menunjukkan adanya senioritas, semuanya berbaur seperti ketika pelaksanaan upacara bendera tidak lagi diberikan blok untuk setiap kelas.

\subsection{Cinta Damai}

Sikap cinta damai ini ditunjukkan melalui sikap siswa yang santun. Ketika pelaksanaan ospek sekalipun tidak menggunakan hukuman fisik sehingga tidak menimbulkan kebencian atau dendam junior kepada seniornya. Demikian pula tidak ada siswa yang berkelahi apalagi sampai melakukan hal-hal yang menyimpang. Semua sadar bahwa kedamaian itu indah.

\subsection{Gemar membaca}

Seperti kata pepatah, buku adalah jembatan ilmu. Seseorang akan mendapatkan pengetahuan tidak hanya dari guru, atau belajar sendiri, namun yang terpenting juga adalah dari membaca. Dengan membaca, pengetahuan seseorang akan bertambah. Dalam Nitisastra dikatakan bahwa ilmu pengetahuan ibaran kamadhuk yang mampu memenuhi segala keinginan. Ilmu pengetahuan ibarat ibu yang akan memelihara manusia dimanapun ia berada. Di SMA 3 Denpasar, pihak sekolah telah memfasilitasi ruangan perpustakaan yang tertata dengan baik, lingkungan yang nyaman, tenang, didukung pula oleh jaringan free Wi-fi selama 24 jam. Perpustakaan di sekolah ini juga telah meraih gelar juara II Perpustakaan terbaik tingkat propinsi. Para siswa juga dianjurkan mengusulkan buku referensi untuk ditambah di perpustakaan, mereka lebih senang menghabiskan waktu luang di perpustakaan daripada berkeliaran di halaman sekolah, terutama pada jam pelajaran yang tidak diisi oleh guru bersangkutan seperti pada gambar berikut.

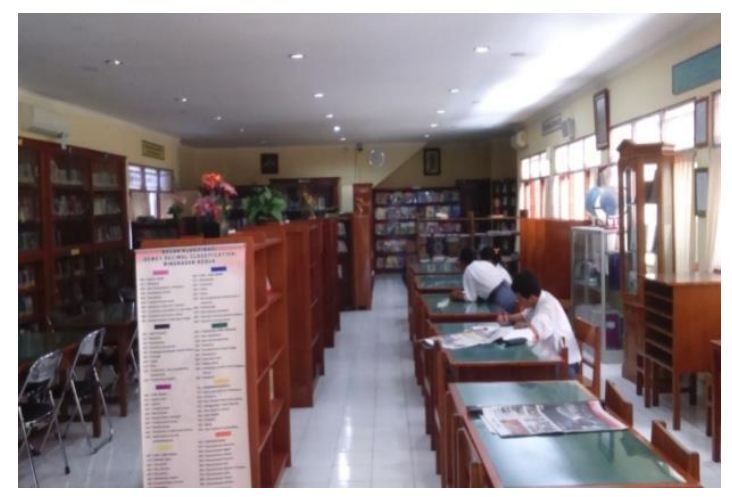

Sumber: dokumentasi penulis 2015

Gambar 4.14

Siswa yang mengisi waktu luang dengan membaca di Perpustakaan 
Para guru diperbolehkan melakukan kegiatan pembelajaran di perpustakaan agar pembelajaran lebih menarik dan tidak membosankan.

\subsection{Peduli lingkungan}

Sikap peduli lingkungan di SMA 3 Denpasar sudah tercantum dalam visi sekolah yakni "Menjadikan siswa cerdas, mandiri, berbudaya, dan berkarakter lingkungan. Karakter peduli lingkungan ini juga diimplementaikan dalam pelaksanaan piket kelas, kemudian dengan sistem telajakan dei depan kelas yang menjadi kewajiban siswa di kelas tersebut untuk merawatnya. Di masing-masing kelas juga diletakkan tanaman hidup dan bambu rejeki di meja guru. Tempat sampah juga disediakan di setiap kelas untuk menjaga kebersihan lingkungan. Siswa memiliki kepedulian terhadap lingkungan mereka seperti tampak pada gambar berikut ini.

Selain itu, ketika perayaan ulang tahun sekolah, dilakukan kegiatan penanaman pohon di lokasi-lokasi yang telah ditentukan.

\subsection{Peduli sosial}

Sebagai mahkluk sosial, manusia memerlukan bantuan orang lain. Banyak orang yang masih kurang beruntung dalam hidupnya yang memerlukan uluran tangan. Inilah yan hendaknya disadari oleh umat manusia. Tidak peduli status sosial seseorang, jika mereka memerlukan bantuan, sudah selayaknya mengulurkan tangan memberi bantuan. Seperti yang telah diterapkan oleh para siswa di SMA 3 Denpasr yakni setiap perayaan ulang tahun sekolah diadakan kegiatan bhakti sosial seperti berkunjung ke panti asuhan maupun panti jompo.

Selain itu, pada tanggal 17 Januari 2013, SMA 3 Denpasar sukses untuk pertama kalinya melakukan bedah rumah di Desa Sumerta. Dana terkumpul dari siswa, dari alumni katrisma, dan dari komite sekolah. Tidak hanya itu, setiap ulang tahun sekolah diadakan pengobatan gratis di banjar-banjar terdekat. Tahun 2014 yang lalu, pihak sekolah telah bekerjasama dengan pemkab Bangli dalam hal bhakti sosial.

\subsection{Tanggung jawab}

Sikap tanggung jawab salah satunya ditunjukkan oleh para siswa ketika berada di perpustakaan, mereka mengatur kursi, merapikan setelah selesai membaca, dan mengembalikan buku pinjaman tepat waktu. Demikian pula ketika mereka melakukan pelanggaran, mereka harus siap menerima sanksi yang diberikan. Ketika terlambat datang ke sekolah misalnya, mereka diberikan sanksi untuk membaca dan merangkum dua buah buku apa saja yang mereka peroleh di perpustakaan sekolah. Para siswa dilaran membawa handphone, dilarang berambut panjang bagi yang pria, dan jika melanggar tentu mereka harus menerima sanksi yang diberikan. Konsekuensi dari sebuah tindakan pasti menimbulkan akibat.

\section{PENUTUP}

Implementasi sikap religius di SMA 3 Denpasar ditunjukkan ketika melakukan Tri Sandhya secara rutin, sembahyang setiap purnama tilem, mengucapkan salam Om Swastyastu ketika bertemu dengan guru. Adanya kantin kejujuran. Toleransi antar siswa berbeda agama. Locker kedisiplinan untuk para siswa yang melakukan pelanggaran. Kerja keras ketika menyiapkan suatu kegiatan termasuk penggalian dananya. Kreativitas dalam memanfaatkan barang bekas sebagai alat musik dan karya seni. Kemandirian saat menyiapkan presentasi. Demokratis saat pemilihan 
pengurus OSIS. Rasa ingin tahu dalam hal penelitian. Semangat kebangsaan dalam upacara pendidikan karaker dan mendaki gunung saat peringatan kemerdekaan RI. Siswa terlibat dalam ekstra tabuh dan tari sebagai bentuk cinta tanah air. Foto siswa berprestasi dipajang di perpustakaan sebagai bentuk penghargaan terhadap prestasi mereka. Sikap bersahabat/ komunikatif antara guru dan siswa. Cinta damai dengan peniadaan hukuman fisik. Gemar membaca didukung oleh fasilitas perpustakaan yang lengkap serta siswa diijinkan untuk mengusulkan buku referensi. Sikap peduli lingkungan terlihat ketika siswa membersihkan telajakan kelasnya masing-masing. Sikap peduli sosial ditunjukkan ketika melakukan bhakti sosial. Tanggung jawab dilihat dari sanksi yang diberikan jika terbukti melanggar.

\section{DAFTAR PUSTAKA}

Daryanto, dan Suryatri Darmiatun. 2013. Impelementasi Pendidikan Karakter di Sekolah. Yogyakarta: Gava Media

Gunawan, Heri. 2012. Pendidikan Karakter, Konsep dan Implementasi. Bandung: Alfabeta.

Kajeng, I Nyoman. 1999. Sarasamuccaya. Surabaya: Paramita.

Mustari, Mohamad. 2014. Nilai Karakter refleksi untuk Pendidikan. Jakarta: PT. Raja Grafindo Persada.

Nashir, Haedar. 2013. Pendidikan Karakter Berbasis Agama \&
Budaya. Yogyakarta: Multi Presindo.

Singer, I Wayan. 2015. Pendidikan Karakter Berlandaskan Tri Kaya Parisudha. Denpasar: PT. Pustaka Manikgeni.

\section{Sivananda, Sri Svami.2003.Intisari Ajaran Hindu. Surabaya, Paramita.}

Titib, I 2003. Menumbuhkembangkan Pendidikan Budhi Pekerti pada Anak (Perspektif Hindu). Jakarta: Ganeca Exact.

Titib, I Made. 2004. Purana, Sumber Ajaran Hindu Komprehensip. Surabaya: Paramita. 